\title{
A COVID-19 KORONAVÍRUS HATÁSA A NAGY ÉSZAK-AMERIKAI SPORTLIGÁKRA
}

\author{
Váczi Péter - Müller Anetta - Bácsné Bába Éva
}

\section{Összefoglalás}

A koronavirus járvány nagy hatással volt az életünk minden területére nem maradt ki ebböl az élsport sem. A járvány okozta belyzetben egy csapásra kerültek rendkivül nebéz, helyzetbe sportklubok, sportšövetségek, de akár egész sportágak is. A sport az utóbbi 20-30 évben üzletté vált, a csúcssportolók pedig termékekkéé váltak. Az. ü̃leti alapon történó sportvállalkozások legmagasabb sæintjei az. Egyesült Államokban és az európai labdarúgópiacon találhatóak meg. Ebben a dolgozatban a koronavírusnak az észak-amerikai franchise rendszerben müködó négy nagy sportligára való hatását fogom megvizsgálni. Nemcsak a vírus okozta batásokat, hanem az, erre sұületett megoldási lehetöségeket is be fogom mutatni, majd megpróbálok. következtetéseket, javaslatokat levonni a feltárt információkból.

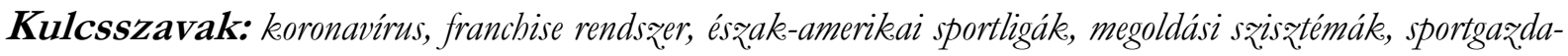
ság

JEL: Z20

\section{EFFECT OF COVID-19 CORONAVIRUS ON MAJOR NORTH AMERI- CAN SPORTS LEAGUES}

\begin{abstract}
The coronavirus epidemic has had a big impact on all areas of our lives, even on elite sports. In the situation caused by the epidemic, sports clubs, sports associations, but even entire sports were in an extremely difficult situation. Sport has become a business in the last 20-30 years, and top athletes have become products. The bighest levels of businessbased sports businesses are found in the United States and the European football market. In this dissertation, I will examine the impact of the coronavirus on the four major sports leagues operating in the North American franchise system. I will present not only the effects caused by the virus, but also the possible solutions, and then I will try to draw conclusions and suggestions from the revealed information.
\end{abstract}

Keywords: coronavirus, franchise system, North American sports leagues, solution systems, economy of sport JEL: Z20 


\section{Bevezetés}

2019 Novemberében Vuhan városából induló koronavírus (Covid-19) rövid idő alatt elterjedt az egész világon. Mivel egy új vírussal van/volt dolgunk ezért nem létezett ellene konkrét vakcina, ezért nagy számban okozott fertőzéseket az egész világon. A gyorsan terjedô vírus hatásai begyúrűztek a sportvilágba is. Világszerte felfüggesztett bajnokságok, elhalasztott nyári olimpia és labdarúgó Európa-bajnokság lett a vírus okozta problémák folyománya. Több sportesemény később folytatódhatott, de nézők nélkül, ami miatt a sportszervezetek a fő bevételi forrásaiktól a jegybevétel, merchandising, vendéglátás, hirdetések, szponzorációs és közvetítési díjak estek el. A pandémiás időszak az egész világ sportjára nagy hatással volt, azonban különbséget kell tenni az Egyesültállamokban mûködő franchise rendszerủ sportligák és a világ többi része között. Én most az ÉszakAmerikában múködő franchise alapú sportligákra gyakorolt hatását szeretném megvizsgálni a koronavírusnak.

\section{Anyag és módszer}

A következő fejezetben az általunk elvégzett szekunder kutatások által szeretnénk bemutatni a franchise rendszer sajátosságait majd a koronavírus hatását a nagy amerikai sportligákra és ennek a krízisnek a megoldási lehetőségeit.

\section{Eredmények}

\section{De mi is az a franchise rendszer?}

Az Egyesült Államokban, a nagy ligákban (NFL, NBA, MLB, NHL, MLS) franchise rendszert használnak, ami teljesen különbözik az Európában használatos bajnoki rendszerektől, ahol a kieséses, feljutásos rendszert preferálják (Pijetlovic, 2015). A franchise fogalmát sokféleképpen határozták meg az évtizedek során.

Martin Mendelsohn angol kutató szerint a következőképpen lehet meghatározni a franchise fogalmát: „, Az üzletszerű franchise az, amikor valaki (a franchise átadó) licencet biztosít valaki másnak (a franchise átvevőnek), ami a franchise átvevôt feljogosítja arra, hogy a franchise átadó védjegye, márkaneve alatt kereskedjen, és hogy felhasználjon egy olyan átfogó csomagot, amely tartalmaz minden szükséges elemet ahhoz, hogy egy korábban képzetlen személyt bevonjon a franchise átadó által kifejlesztett üzletbe, s azt egy előre lefektetett alapon folytonos segítségnyújtás mellett futtassa " (Mendelsohn, 1991).

A következő karakterisztikáknak kell jelen lenniük ahhoz, hogy franchise rendszerrôl lehessen beszélni:

- Egy franchise rendszerhez legalább két szereplőre van szükség, egyikük a franchise átadó, másikjuk a franchise átvevő;

- Az átadó és az átvevő jogilag és gazdaságilag önálló, független vállalkozók, akik saját kockázatukra és hasznukra tevékenykednek; 
- Az átadónak rendelkeznie kell egy már bevezetett, bizonyítottan sikeres, márkanévvel/védjeggyel jelzett és védett üzleti tevékenységgel, amelynek piaci értéke van, és ezt mások elismerik, elfogadják és fizetnek érte;

- Az üzleti tevékenység valamilyen áru/szolgáltatás/technológia értékesítésére irányul;

- Szükség van egy szerződésre, amely meghatározott időre szól és kitér mind a két fél jogaira és kötelezettségeire;

- Az átvevő saját, vagy általa felvett hitelből finanszírozott tőkét fektet be, amely fokozza elkötelezettségét, felelősségvállalását és kockázatát;

- Az átadó átvevőjét megtanítja az adott tevékenység folytatására, annak minden részletére, és segíti átvevőjét vállalkozási tevékenységének megkezdésében;

- Az átadó folyamatosan köteles segíteni átvevőjét a vállalkozás minden területén;

- Az átvevő előre megállapodott formákban és mértékekben fizet az átadónak azokért a jogokért, melyekkel rendelkezik, valamint a rendelkezésére bocsátott szolgáltatásokért;

- Az átvevő általában egy földrajzilag jól körülhatárolható területre kizárólagos működési jogot kap átadójától;

- A feleknek kölcsönösen tudatában kell lennie annak, hogy egyikük hibája és sikertelensége előbb-utóbb a másik sikertelenségéhez és a rendszer kudarcához vezethet (Jánosi, 1991).

A franchise rendszer először a baseball sportágban jelent meg 1876-ban. A rendszer kiváltságokat garantált a franchise-ban részt vevô csapatok számára a szúkebb geográfiailag értelmezett térben (az Amerikai Egyesült Államok szerkezetébe illő tagállamot jelentette). Ez a modell is hozzájárult ahhoz, hogy a baseball sportágban indult az első szervezett bajnokság az Egyesült Államokban. A szervezettség által a legnagyobb profitot hozó sportággá vált. Pontosan ezért a későbbiekben más sportágak is a baseballban jól múködő „üzleti modellt” kezdték el követni. Az üzleti fejlődés által a geográfiai előnyök városok tekintetében realizálódtak. A sportligák gyors fejlődése révén egyre több és több város csapata csatlakozott a franchise rendszerhez. A csapatok növekvő száma megkívánta a teljesen üzleti alapon múködő modellt és a rögzített szabályok teljes betartását. Nem véletlen, hogy az európai piramis szerúen felépülő sportstruktúrában az amatôr és a profi sport nem különül el egymástól élesen, ezzel szemben az Egyesült Államokban éles határ van az amatőr és a profi sport között. „Az amerikai sportmodell, szemben az európaival, lényegében teljesen zártnak tekinthető: a major sport ligákban jellemzően 30-32 csapat múködik, és sem feljutásra, sem pedig kiesésre nincs lehetôség. A jogalkotó által biztosított keretek, illetőleg az adott liga szervezeti szabályzatának keretei között a ligák tulajdonosai dönthetnek arról, hogy hány csapat és milyen szervezetben vehet részt az adott ligában. Ebből a megközelítésből azonban sok minden egyéb is következik. Az amerikai piacon az igazi bevételt nem az egyes csapatok, hanem maguk a ligák jelentik, ekként egyrészt a bevételek elosztása is lényegesen kiegyenlítettebb, mint az európai sportmodellben, másrészt pedig maguk a ligák is abban érdekeltek, hogy egyetlen csapat se domináljon hoszszabb időn keresztül, mert az az adott sportág eseményei iránti érdeklődés csökkenésével (és ez által a liga-szintú bevételek csökkenésével) jár. Ez azt eredményezi, hogy, amíg az amerikai sportmodellben a csapatokat múködtető gazdasági társaságok horizontálisan (a liga szintjén) integrálódtak, addig az európai sportmodellben vertikális integrációt figyelhetünk meg: amíg az Egyesült Államokban a piac és a bevételek szempontjából a csapatok együtt dolgoznak és csak a pályán küzdenek egymással szemben, addig Európában gyakorlatilag a klubcsapatok minden szempontból riválisai egymásnak (Szemesi, 2015). A gazdasági piacon közösen lépnek fel ezek a franchiseok így ez a közös fellépés kereskedelmi bevételi lehetőséget ad a franchiseok számára. A liga úgynevezett Joint Venture rendszerben múködik, amit közös vállalkozási rendszernek lehetne lefordítani. Az 
Váczi P. - Müller A. - Bácsné Bába É.

NBA szervezeti szabálya is kimondja, hogy egy olyan szervezet, amelyben emberek közösen dolgoznak egy közös cél eléréséért (Grossman, et al., 2014).

\section{A koronavírus hatása a nagy amerikai sportligákra}

Veszteségek:

Nba:

- A jegybevétel kiesés 450 millió dollár környékén volt, a nem jegy típusú bevétel kiesés 200 millió dollár volt,

- A liga márciusi felfüggesztése miatt 259 alapszakasz mérkőzés maradt el. Később a bajnokságot egy izolált helyszínen befejezték,

- A 259 nézők nélküli elmaradt alapszakasz mérkőzés 300 millió dolláros kiesést jelentett,

- A Los Angeles Lakers (a későbbi bajnok) csapatának 82,1 millió dolláros kiesést jelentettek az elmaradt mérkőzések.

\section{Nfl-amerikai futball:}

- Mivel a szezon szeptemberben egységesen nézők nélkül indult, ezért csapatonként átlagban 100 millió dolláros bevétel kieséssel lehet számolni,

- A liga egyik legnépszerűbb csapatánál a New England Patriots-nál a jegybevétel kiesés 376 millió dollár lesz az elemzők szerint.

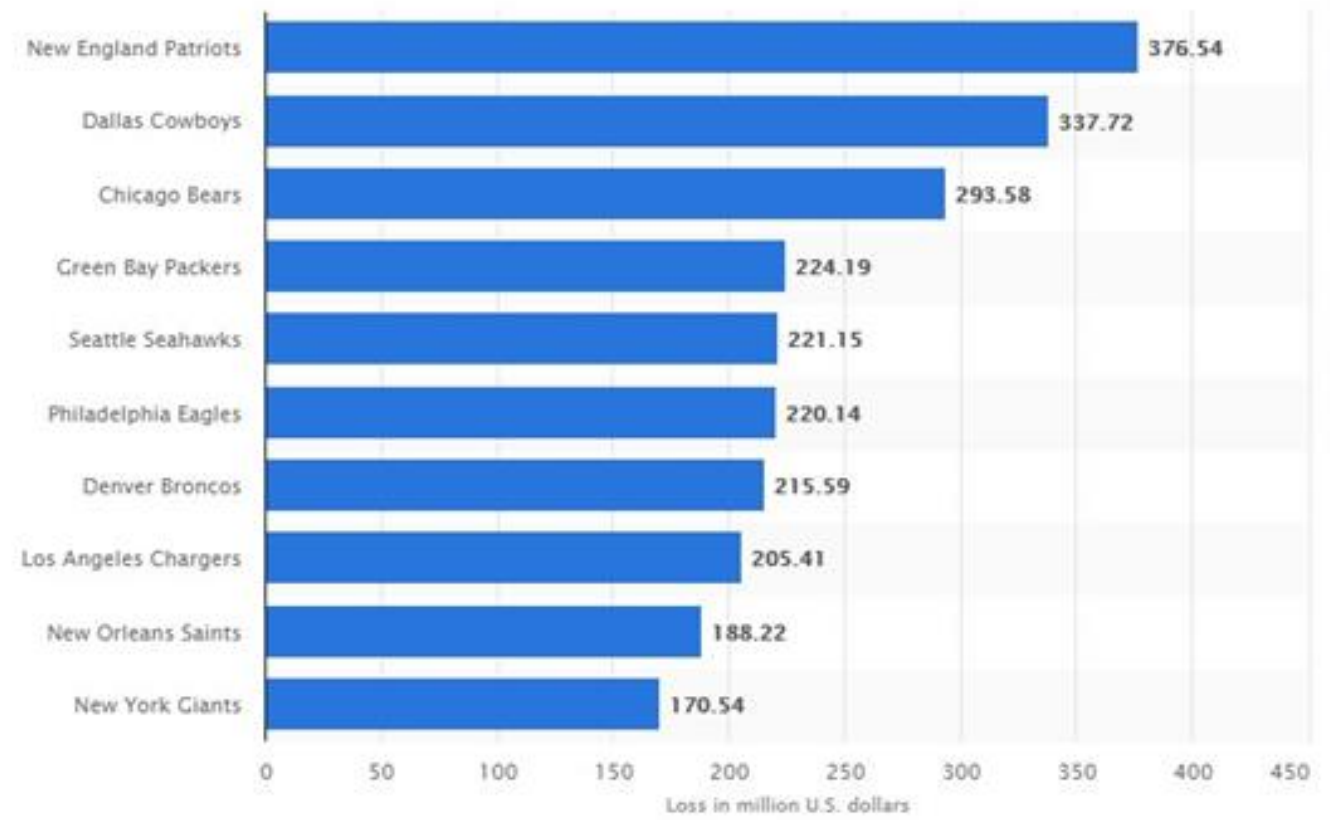

1. ábra. A legnagyobb jegybevétel kiesések az Nfl csapatoknál (millió dollár)

Forrás: https:// wmw.statista.com/ statistics/1130256/ ticket-revenue-loss-nfl-coronavirus-team/ 


\section{Baseball}

- A bajnokság indításának elhalasztásával a New York Yankees csapata 470 millió dolláros jegybevétel kiesést volt kénytelen elkönyvelni,

- A Cardinals és a Cubs közötti londoni mérkőzést törölték,

- A 2020 évi All Star Game-t törölték,

- A 60 mérkőzéses alapszakasz Július 23-24.-én elkezdődik,

- A szezon végül rövidített formában megrendezésre került, amelyet a Los Angeles Dodgers csapata nyert meg.

\section{NHL - Jégkorong}

- A jégkorong liga viszonylagos jó helyzetben volt tavasszal, mert a csapatok a 41 hazai mérkőzésük közül átlagban 32-37 mérkőzést lejátszottak. Így az alapszakaszban az elmaradó mérkőzések utáni jegybevétel kiesés átlagban 1,31 millió dollár volt elmaradó hazai mérkőzésenként,

- A szezon szeptember 28-án a Tampa Bay győzelmével fejeződött be, ami a második Stanley Kupa győzelmüket jelentette. (Rosen,2020),

- A bajnoki szezont március 12-én függesztették fel (https://www.nhl.com/news/nhlcoronavirus-status/c-316155530),

- Május 22-én határoztak arról, hogy folytatják az idényt egy 24 csapatos playoff szisztémával, zárt kapuk mögött,

- Július 10-én bejelentik, hogy két központi helyszínen Torontóban és Edmontonban zajlik majd a teljes playoff programja. Mindkét városban úgynevezett buborékot alakítanak ki (Benz,2020), amelyben csak a sportolók és a csapatokhoz tartozó stáb lehet, onnan kijárás és külsős személyeknek bejutás nem lehetséges és a bent lévő sportolókat, stábokat folyamatosan tesztelik, természetesen nézők nem vehetnek rész a mérkőzéseken,

- A sorozat döntőjének a helyszíne Edmonton volt.

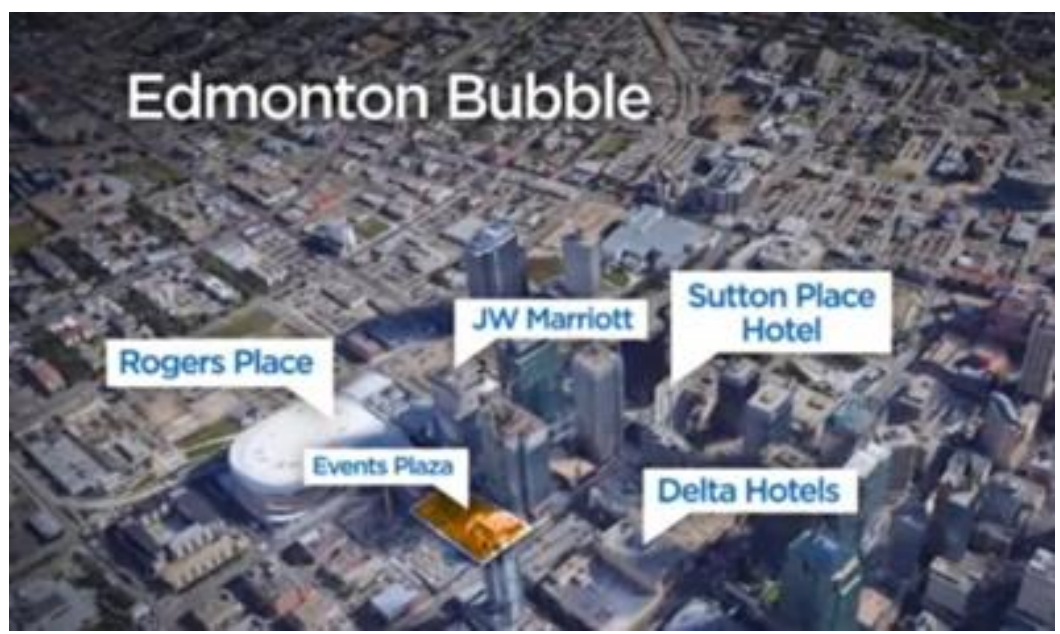

2. ábra. Az edmontoni buborék területe, ahol csak a rájátszásban részt vevő csapatok tartózkodhattak.

Forrás: https://globalnews.ca/ news/7215190/rogers-place-ready-nhl-playoffs / 


\section{A buborék megoldás}

Az előző részben már volt szó a buborék megoldásról, egy sportcsarnokokat és hoteleket magában foglaló városrész lezárásáról, ahová csak a sportolók és a csapatokhoz tartozó személyek lehetnek jelen és folyamatosan tesztelik őket. Szeretném most ezt a megoldást részletesen megoldani, hiszen az NBA és az NHL mintájára nagyon sok nemzeti és nemzetközi szövetség vette át ezt a megoldás különféle sportágakban.

Az a megoldás, amit a Covid járvány miatt európai bajnokságok megoldásként hoztak, hogy nem fejezik be a saját bajnokságukat, az itt fel sem merülhetett, hiszen olyan pénzek forognak a bajnokságban, amely miatt mindenképpen megoldást kellett találni. Jól mutatja az összegek nagyságát a következő ábra, ahol a 2018/19 szezon 10 legmagasabb bevételű csapat adatai láthatóak millió dollárban.

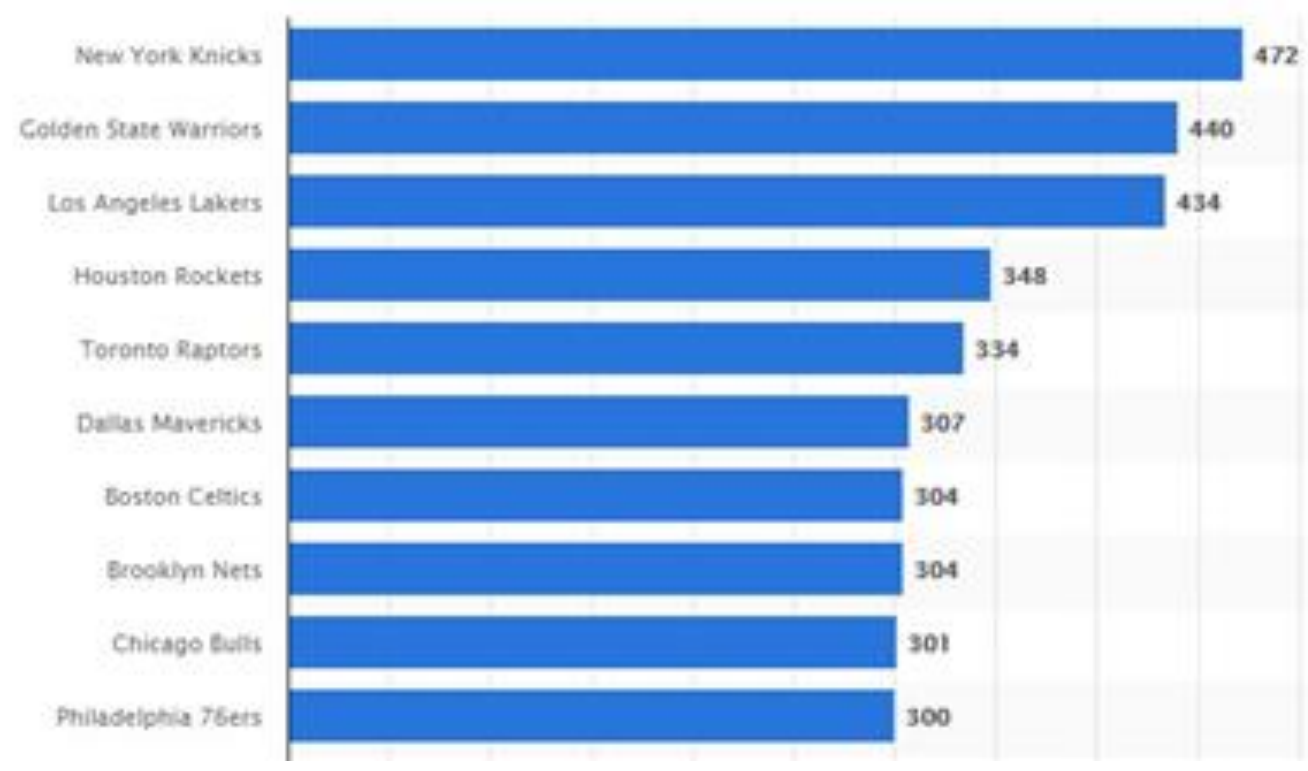

3. ábra. A tíz legmagasabb bevételű csapat az Nba 2018/19. szezonjában

Forrás: https:// wmm.statista.com/statistics/193704/ revenue-of-national-basketball-association-teams-in-2010/

2020 márciusában produkált az első játékos pozitív Covid tesztet, amely után a bajnokságot felfüggesztették. Azonban akkora pénzek forognak kockán, akár a tulajdonosi oldalt, akár maga a liga bevételeit, akár a játékosok juttatatásait nézve, hogy valamilyen megoldást ki kellett találni az idény befejezésére, természetesen maximálisan figyelembe véve az egészségügyi szempontokat.

A buborék megvalósítását Floridában található Disneyland területén valósították meg. Az NBA vezetősége a klubtulajdonosokkal és a játékosokkal megállapodva 2020. július 7. és 2020. október 10. között kvázi egy karanténba helyezte 22 csapat játékosait, akiknek igen szigorú, több mint 100 oldalban leírt protokoll mellett kellett lejátszaniuk csapatonként nyolc alapszakasz mérkőzést és a teljes hagyományos formátumú rájátszást (extraként még volt egy play-in mérkőzés is a rájátszásért). (https://concordeblog.hu/2020/10/13/volt-egyszer-egy-nba-buborek/)

Utólag elmondható, hogy helyes döntések voltak ezek, hiszen pozitív teszt nélkül lement a buborékon belül és ugyan a belépő jegyek árát elbukta a liga és maga a buborék költségei is 180 millió dollára (50 milliárd forint) rúgtak, de a legfontosabb szempont a bajnokság befejezése volt. A méretek érzékeltetésére, a kialakított buborék két Manhattan nagyságú volt, amely így körülbelül 110 $\mathrm{km}^{2}$ nagyságúnak volt mondható. 


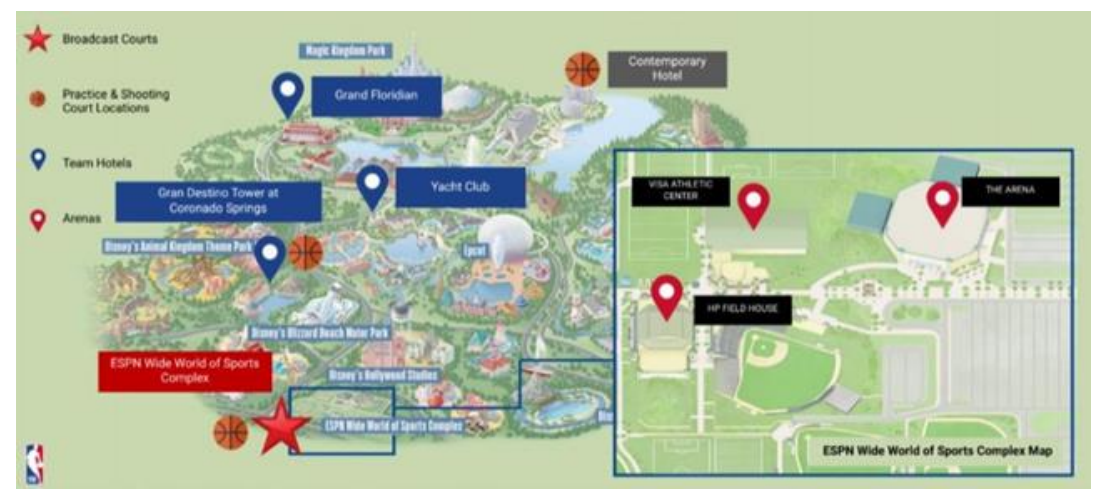

4. ábra. A buborék térképe

Forrás: : https:// wmw.laugbingplace.com/w/news/2020/06/16/nba-teams-assigned-to-walt-disney-worldresorts-based-on-tournament-seeds/

A buborékon belül 7 gyakorló pálya és 3 mérkőzés rendezésére alkalmas pálya lett kialakítva. (https://thesportsrush.com/nba-news-how-many-courts-are-in-the-nba-bubble-completeorlando-bubble-courts-information/)

A buborékba 22 csapat költözött be, a mérkőzések augusztus 17 és október 11 között kerültek megrendezésre. Amint már említettem a megoldás tökéletesen bevált. A nagy rendezési költségek ellenére a szezon végigment, a tévétársaságok közvetítéseiből nem kevés bevétel származott a csapat tulajdonosok is megnyugodhattak és a szponzorok is elégedettek lehettek ezzel a megoldással. Nem véletlenül másolják most ezt a megoldást kicsiben az egész világon a pandémiás időszakban a labdajátékok küzdelmeinél.

\section{Köveztetések és javaslatok}

A világ 10 legértékesebb sportbajnoksága közül az első három helyen észak-amerikai sportligák állnak (amerikai futball, baseball, kosárlabda), de a jégkorong bajnokság is a hatodik legértékesebb a világon. Könnyen belátható, hogy ezek a ligák nem tehették meg, hogy csak úgy lefújják a bajnokságukat és ne hirdessenek győztest.



5. ábra. A 10 legnagyobb sportliga bevétele milliárd dollárban a 2019 évben

Forrás: bttps:/ / wwm.bizvibe.com/ blog/largest-sports-leagues-by-revenue 
A legnehezebb helyzetben a kosárlabda és a jégkorong volt, hiszen a vírus helyzet tavaszi csúcspontja éppen a bajnoki versenyrendszer közepébe hozott megoldandó szituációt. Nem véletlen, hogy ez a két bajnokság „,találta” fel úgymond a buborék rendszert. A baseball talán kissé könnyebb helyzetben volt, hiszen szabadtéri sportról van szó, ahol rövidebb alapszakasszal, a nézők kizárásával, szigorú egészségügyi szabályokkal le tudtak játszani egy rövidített szezont. Míg az amerikai futballban éppen szünet volt, ahol igazából a csapatok felkészülésébe zavart be a vírushelyzet. Most jelenleg limitált nézői részvétellel, drákói szigorúságú egészségügyi szabályokkal, kisebb zökkenőkkel, de múködik a bajnokság.

A franchise rendszer felépítése miatt, (hiszen itt nincsenek kieső csapatok), ezeknek a csapatoknak a dúsgazdag tulajdonosaik miatt, akik a saját pénzüket fektetik be, a rendkívül magas televíziós jogdíjak miatt, az ajándéktárgyakból (merchandising) befolyt bevételek miatt és a szponzori pénzek nagysága miatt egyszerúen ezeknek a bajnokságnak kellett, hogy legyen eleje és vége, gyakorlatilag pénzügyi megoldásokat nézve szinte mindegy mibe kerül. Gondoljunk itt a magyar pénzben 50 millárd forintból megvalósított NBA buborék szisztémára.

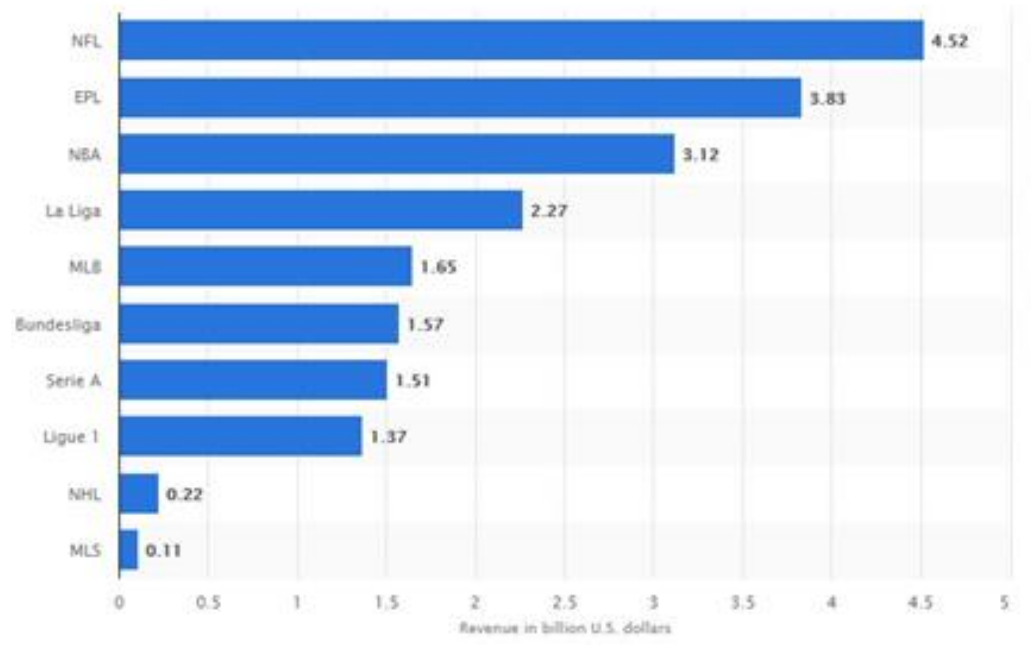

\section{6. ábra. közvetítési jogok árai a világ 10 legértékesebb sportligájában 2019-ben}

Forrás: https:/ / mww.statista.com/statistics/1120170/broadcasting-rights-sports-by-league/

Mára a sport akkora üzletté vált, hogy a shownak mennie és folytatódnia kell. Az Egyesült Államok nagy bajnokságainál ezt meg is tudták oldani, mégpedig úgy, hogy az egészségügyi ajánlásokat is maximálisan be tudták tartani. Emellett még az üzleti szempontokat maximálisan figyelembe véve mennie kellett a mérkőzéseknek, még úgy is, hogy nézők nem lehettek jelen, ami például az Nba esetében átlagban 16.000-20.000 néző kiesését jelentette mérkőzésenként. (Pedersen et al., 2020) Jelenleg úgy látszik, hogy a következő, idények sem lesznek könnyűek, de az ésszerűen meghozott döntések miatt a ligák túl fogják élni a koronavírus krízist és legalább a jelenlegi színvonalon, ha nem magasabb színvonalon fognak tudni a jövőben múködni. Nem vitás a világ újra tudott tanulni az észak-amerikai sportligák döntéseiből, válságenyhítő megoldásaiból. 


\section{Köszönetnyilvánítás}

A publikáció elkészítését a “GINOP-2.3.2-15-2016-00062 Életminőség fejlesztése Kelet-Magyarországon: Táplálkozás-, teljesítménybiológiai és biotechnológiai experimentális kutatások és eszközfejlesztések a humán megbetegedések megelőzésére és kezelésére” projekt támogatta.

\section{Hivatkozott források}

[1.] Balogh R. - Dajnoki K. - Bácsné Bába É. (2019): Miért beteg a magyar futball még mindig? A magyar labdarúgás játékos piacának jellemzése. Jelenkori Társadalmi és Gazdasági Folyamatok, 13(3-4), 105-117.

[2.] Benz, Tim (2020): A look at how Toronto 'bockey bubble' will be set up for Penguins. Pitts-burgh Tribune-Review. Retrieved August 1, 2020.

[3.] Grossman, A. - Shields, B. - Rein, I.: (2014): The Sports Strategist: Developing Leaders for a HighPerformance Industry. Oxford University Press 1st edition p. 288.

[4.] Jánosi István (1991): A franchise, valamint helyzete és lehetöségei Magyarországon doktori értekezés. Budapesti Közgazdaságtudományi Egyetem. p. 11.

[5.] Jónap R. (2020): Volt egyszer egy NBA-buborék. Letöltés dátuma: 2020. 10. 27. forrás: https://concordeblog.hu/2020/10/13/volt-egyszer-egy-nba-buborek/

[6.] Mendelsohn, M. - Acheson, D. (1991): Franchise a gyakorlatban. A névjoglás ABC-je. Hit Investcenter-Tradeinform p. 79.

[7.] Pedersen, P. M. - Brody, J. R. - Bo, L. (2020): Sport and the Pandemic: Perspectives on Covid-19's Impact on the Sport Industry. Routledge; 1 st edition. September 29, 2020

[8.] Pijetlovic, K. (2015): EU Sports Law and Breakaway Leagues in Football. T.M.C. Asser Press; 2015 edition p. 310.

[9.] Szemesi S. (2015): Nemzetköri és európai sportjog. Campus Kiadó p. 118.

[10.] Szerző nélküli. NHL statement on coronavirus. Letöltés dátuma: 2020.10.25. forrás: https://www.nhl.com/news/nhl-coronavirus-status/c-316155530

[11.] Tanish, T. (2020): How many courts are in the NBA Bubble: Complete Orlando Bubble Courts information. Letöltés dátuma: 2020.10.29. forrás: https://thesportsrush.com/nbanews-how-many-courts-are-in-the-nba-bubble-complete-orlando-bubble-courtsinformation/

\section{Szerzők}

Váczi Péter

Phd

Adjunktus

Eszterházy Károly Egyetem Eger Sporttudományi Intézet

vaczi.peter@uni-eszterhazy.hu

Müller Anetta

Phd 
Váczi P. - Müller A. - Bácsné Bába É.

Egyetemi docens

Debreceni Egyetem, Gazdaságtudományi Kar, Sportgazdasági és -menedzsment Intézet muller.anetta@,econ.unideb.hu

Bácsné Bába Éva

Egyetemi tanár

Debreceni Egyetem, Gazdaságtudományi Kar, Sportgazdasági és -menedzsment Intézet bacsne.baba.eva@econ.unideb.hu 
